\title{
Synthesis and Crystal Structure of trans-Diiodobis(piperidine-1-carbonitrile)platinum(II)
}

\author{
Aleksey L. Mindich, ${ }^{1}$ Matti Haukka, ${ }^{2}$ and Nadezhda A. Bokach ${ }^{1}$ \\ ${ }^{1}$ Department of Chemistry, Saint Petersburg State University, Universitetsky Pr. 26, Stary Petergof 198504, Russia \\ ${ }^{2}$ Department of Chemistry, University of Jyväskylä, P.O. Box 35, 40014 Jyväskylä, Finland \\ Correspondence should be addressed to Nadezhda A. Bokach; n.bokach@spbu.ru
}

Received 24 May 2013; Accepted 3 October 2013

Academic Editors: M. Akkurt, J. Jasinski, T. Mino, P. R. Raithby, and E. Suresh

Copyright (C) 2013 Aleksey L. Mindich et al. This is an open access article distributed under the Creative Commons Attribution License, which permits unrestricted use, distribution, and reproduction in any medium, provided the original work is properly cited.

Treatment of dichlorobis(piperidine-1-carbonitrile)platinum(II) with potassium iodide in water/methanol mixture results in the halide ligand exchange giving novel trans-diiodobis(piperidine-1-carbonitrile)platinum(II) complex. The reaction proceeds under mild conditions $\left(20^{\circ} \mathrm{C}, 40 \mathrm{~min}\right)$ giving trans- $\left[\mathrm{PtI}_{2}\left(\mathrm{NCNC}_{5} \mathrm{H}_{10}\right)_{2}\right]$ in $70 \%$ isolated yield. The iodide complex was characterized by $\mathrm{IR}$, ${ }^{1} \mathrm{H}$ and ${ }^{13} \mathrm{C}$ NMR spectroscopies, and high resolution ESI-MS, and its structure was determined by a single crystal X-ray diffraction.

\section{Introduction}

Interest in metal complexes bearing $\mathrm{NCR}(\mathrm{R}=\mathrm{Alk}, \mathrm{Ar}$, $\mathrm{NAlk}_{2}$ ) ligands is stimulated by enhanced reactivity of nitrile functionality in such compounds toward nucleophilic addition and 1,3-dipolar cycloaddition [1,2]. Moreover, these metal-mediated processes allow the conductance of the reactions, which are not feasible without involvement of metal centers. Our recent results demonstrate unexpectedly high activity of platinum(II)-bound push-pull nitriles NCNAlk toward cycloaddition of nitrones and nucleophilic additions [3]. Following this project focused on investigations of unusual reactivity of push-pull nitrile ligands, we studied novel platinum(II) complex bearing push-pull dialkylcyanamide ligands.

\section{Materials and Methods}

All reagents and solvents were obtained from commercial sources and used as received. Isomeric mixture of approximately 1:1 cis/trans-dichlorobis(piperidine-1-carbonitrile)platinum(II) was prepared in accordance with the published method [4]. Infrared spectrum was recorded on a Shimadzu FTIR $8400 \mathrm{~S}$ instrument in $\mathrm{KBr}$ pellets. ${ }^{1} \mathrm{H}$ and ${ }^{13} \mathrm{C}$ NMR spectra were measured on a Bruker-DPX 300 and Bruker $400 \mathrm{MHz}$ Avance spectrometers at ambient temperature. Electrospray ionization mass spectrum was obtained on a Bruker micrOTOF spectrometer equipped with electrospray ionization (ESI) source and $\mathrm{MeOH}$ was used as the solvent. The instrument was operated at positive ion mode using a $m / z$ range of 50-3000.

2.1. X-Ray Crystal Structure Determination. The crystal of of trans- $\left[\mathrm{PtI}_{2}\left(\mathrm{NCNC}_{5} \mathrm{H}_{10}\right)_{2}\right]$ was immersed in cryo oil, mounted in a Nylon loop, and measured at a temperature of $100 \mathrm{~K}$. The X-ray diffraction data was collected on Bruker Kappa Apex II Duo diffractometer using Mo K $\alpha$ radiation $(\lambda=0.71073 \AA)$. The SAINT program package [5] was used for cell refinement and data reduction. The structure was solved by direct methods using SHELXS-97 [6] program with a WinGX [7] graphical user interface. A numerical absorption correction (SADABS) [8] was applied to data. Structural refinement was carried out using SHELXL-97 [6]. Hydrogen atoms were positioned geometrically and constrained to ride on their parent atoms, with $\mathrm{C}-\mathrm{H}=0.99$ and $\mathrm{U}_{\text {iso }}=1.2 \cdot \mathrm{U}_{\mathrm{eg}}$ (parent atom). The crystallographic details are summarized in Table 1 and selected bond lengths and angles in Table 2.

2.2. Preparation of trans- $\left[\mathrm{PtI}_{2}\left(\mathrm{NCNC}_{5} \mathrm{H}_{10}\right)_{2}\right]$. Water solution $(0.5 \mathrm{~mL})$ of $\mathrm{KI}(41 \mathrm{mg}, 0.25 \mathrm{mmol})$ was added to a suspension of cis/trans- $\left[\mathrm{PtCl}_{2}\left(\mathrm{NCNC}_{5} \mathrm{H}_{10}\right)_{2}\right](49 \mathrm{mg}, 0.1 \mathrm{mmol})$ in 
TABLE 1: Crystallographic details for trans- $\left[\mathrm{PtI}_{2}\left(\mathrm{NCNC}_{5} \mathrm{H}_{10}\right)_{2}\right]$.

\begin{tabular}{lc}
\hline Empirical formula & $\mathrm{C}_{12} \mathrm{H}_{20} \mathrm{I}_{2} \mathrm{~N}_{4} \mathrm{Pt}$ \\
Fw & 669.21 \\
Temp. $(\mathrm{K})$ & $100(2)$ \\
$\lambda(\AA)$ & 0.71073 \\
Cryst syst & Monoclinic \\
Space group & $P 2_{1} / c$ \\
$a(\AA)$ & $6.7497(7)$ \\
$b(\AA)$ & $15.8212(16)$ \\
$c(\AA)$ & $8.2773(8)$ \\
$\beta($ deg $)$ & $104.110(4)$ \\
$\left(\AA^{3}\right)$ & $857.25(15)$ \\
$Z$ & 2 \\
$\rho_{\text {calc }}\left(\mathrm{Mg} / \mathrm{m}^{3}\right)$ & 2.593 \\
$\mu(\mathrm{Mo} \mathrm{K} \alpha)\left(\mathrm{mm}^{-1}\right)$ & 11.779 \\
Number of reflections & 27391 \\
Unique reflections & 4203 \\
$\mathrm{GOOF}\left(\mathrm{F}^{2}\right)$ & 1.229 \\
$R_{\text {int }}$ & 0.0257 \\
$R 1^{\mathrm{a}}(I \geq 2 \sigma)$ & 0.0160 \\
$w R 2^{\mathrm{b}}(I \geq 2 \sigma)$ & 0.0377 \\
\hline${ }^{\mathrm{a}} R 1=\sum\left\|F_{o}|-| F_{c}\right\| / \sum\left|F_{o}\right|{ }^{\mathrm{b}} w R 2=\left[\sum\left[w\left(F_{o}^{2}-F_{c}^{2}\right)^{2}\right] / \sum\left[w\left(F_{o}^{2}\right)^{2}\right]\right]^{1 / 2}$.
\end{tabular}

$\mathrm{MeOH}(0.5 \mathrm{~mL})$. The reaction mixture was intensively stirred for $40 \mathrm{~min}\left(20-25^{\circ} \mathrm{C}\right)$ and then was left to stand at $-5^{\circ} \mathrm{C}$ for $3 \mathrm{~h}$. The resulting solid was filtered off and washed with cold methanol/water mixture (two $0.5-\mathrm{mL}$ portion) and dried on air to give trans- $\left[\mathrm{PtI}_{2}\left(\mathrm{NCNC}_{5} \mathrm{H}_{10}\right)_{2}\right]$ as the light-yellow solid (47 mg, 70\%).

Elemental analysis, Pt: $29.27 \%$ (29.15\%, calcd). High resolution $\mathrm{ESI}^{+}-\mathrm{MS}, m / z: 542.0331[\mathrm{M}-\mathrm{I}]^{+}$(542.0381 calcd), $691.9263[\mathrm{M}+\mathrm{Na}]^{+}(691.9323$ calcd $)$. IR spectrum in $\mathrm{KBr}$, selected bands, $\mathrm{cm}^{-1}: 2941 \mathrm{~s}, 2864 \mathrm{~s} v(\mathrm{C}-\mathrm{H}), 2293 \mathrm{~s} v(\mathrm{C} \equiv \mathrm{N})$. ${ }^{1} \mathrm{H}$ NMR $\left(300.13 \mathrm{MHz}, \mathrm{CDCl}_{3}\right): \delta 3.32\left(\mathrm{t}, 8 \mathrm{H}, \mathrm{NCH}_{2}\right), 1.76-$ $1.65\left(\mathrm{~m}, 8 \mathrm{H}, \mathrm{NCH}_{2} \mathrm{CH}_{2}\right), 1.65-1.56\left(\mathrm{~m}, 4 \mathrm{H}, \mathrm{NCH}_{2} \mathrm{CH}_{2} \mathrm{CH}_{2}\right)$. ${ }^{13} \mathrm{C}\left\{{ }^{1} \mathrm{H}\right\} \quad \mathrm{NMR} \quad\left(100.61 \mathrm{MHz}, \mathrm{CDCl}_{3}\right): \delta \quad 118.8 \quad(\mathrm{NCN})$, $49.9\left(\mathrm{NCH}_{2}\right), 24.7\left(\mathrm{NCH}_{2} \mathrm{CH}_{2}\right), 22.6 \quad\left(\mathrm{NCH}_{2} \mathrm{CH}_{2} \mathrm{CH}_{2}\right)$ (Scheme 1).

\section{Results and Discussion}

3.1. Synthesis of trans- $\left[\mathrm{PtI}_{2}\left(\mathrm{NCNC}_{5} \mathrm{H}_{10}\right)_{2}\right]$. General route to iodide platinum(II) complexes bearing two neutral ligands is the exchange reaction between $\mathrm{K}_{2}\left[\mathrm{PtCl}_{4}\right]$ and excess $\mathrm{KI}$ in water followed by reaction with neutral ligands [9-12]. In our case, this reaction was unselective and furnished the target compound in low yield with concomitant formation of the platinum black as the by-product.

Trans-diiodobis(piperidine-1-carbonitrile)platinum(II) complex (trans- $\left[\mathrm{PtI}_{2}\left(\mathrm{NCNC}_{5} \mathrm{H}_{10}\right)_{2}\right]$ ) was obtained as the light-yellow solid by the reaction of dichlorobis(piperidine1-carbonitrile)platinum(II) with potassium iodide in water/ methanol mixture under mild conditions $\left(20^{\circ} \mathrm{C}, 40 \mathrm{~min}\right)$ in $70 \%$ isolated yield. Strong trans-effect of iodide ligands determines the selective generation of the trans-isomer and allows the use of the cis/trans mixture of the starting of $\left[\mathrm{PtCl}_{2}\left(\mathrm{NCNC}_{5} \mathrm{H}_{10}\right)_{2}\right]$ complex [4]. The advantages of this method are also mild reaction conditions, facile isolation, and high yield of the reaction product.

3.2. Characterization of trans- $\left[\mathrm{PtI}_{2}\left(\mathrm{NCNC}_{5} \mathrm{H}_{10}\right)_{2}\right]$. In $\mathrm{ESI}^{+}$ mass spectrum, only two intensive signals with characteristic isotopic pattern of $[\mathrm{M}-\mathrm{I}]^{+}$and $[\mathrm{M}+\mathrm{Na}]^{+}$were detected. In IR spectrum of the title compound, the most characteristic band is from $\mathrm{C} \equiv \mathrm{N}$ stretching vibrations $\left(2293 \mathrm{~cm}^{-1}\right)$. This value is higher than that in free 1-piperidinecarbonitrile $\left(2210 \mathrm{~cm}^{-1}\right)[13]$ and is very close to $\nu(\mathrm{C} \equiv \mathrm{N})$ bond in trans$\left[\mathrm{PtCl}_{2}\left(\mathrm{NCNC}_{5} \mathrm{H}_{10}\right)_{2}\right]\left(2292 \mathrm{~cm}^{-1}\right)$ [4]. In ${ }^{1} \mathrm{H} \mathrm{NMR}$, only one set of signals corresponding to the methylene groups of the piperidine ring was observed. The most characteristic signal in ${ }^{13} \mathrm{C}$ NMR spectrum, sensitive to structure changes, is the one from NCN fragment at $118.8 \mathrm{ppm}$.

A single-crystal $\mathrm{X}$-ray diffraction study was performed for a crystal grown by the slow evaporation of $\mathrm{CH}_{2} \mathrm{Cl}_{2} /{ }^{\mathrm{n}} \mathrm{Bu}_{2} \mathrm{O}$ $(2: 1, \mathrm{v} / \mathrm{v})$ solution of trans- $\left[\mathrm{PtI}_{2}\left(\mathrm{NCNC}_{5} \mathrm{H}_{10}\right)_{2}\right]$ (Figure 1$)$. The coordination polyhedron of the compound is formed by two piperidine-1-carbonitrile ligands in the trans-orientation and two iodide ligands, resulting in a typical square planar geometry.

Bond angles around the platinum(II) center are very close to $90^{\circ}\left(89.31(5)^{\circ}\right.$ and $\left.90.69(5)^{\circ}\right)$. The $\mathrm{Pt}(1)-\mathrm{I}(1)$ distances $(2.6117(2) \AA)$ are typical for Pt-I bonds $[14,15]$. The Pt(1)$\mathrm{N}(1)$ (1.9537(15) $\AA$ ) bond length is equal to such bonds in similar platinum(II) complexes bearing push-pull nitriles [4, 16]. The $\mathrm{Pt}(1)-\mathrm{N}(1)-\mathrm{C}(1)$ and $\mathrm{N}(1)-\mathrm{C}(1)-\mathrm{N}(2)$ fragments are nearly linear with bond angles of $178.37(15)^{\circ}$ and $178.1(2)^{\circ}$, correspondingly. The bond distance $\mathrm{N}(1)-\mathrm{C}(1)(1.153(2) \AA)$ is equal, within $3 \sigma$, to the distance in similar complexes with push-pull $\mathrm{NCNR}_{2}[4,16]$ or with conventional NCR nitriles $[17,18]$. The bond $\mathrm{C}(1)-\mathrm{N}(2)(1.314(2) \AA)$ is shorter than a regular single $\mathrm{C}-\mathrm{N}$ bond and it is close to the typical $\mathrm{C}=\mathrm{N}$ bond [19]. This could be explained by a significant contribution of the structure $\mathrm{Pt}-\mathrm{N}^{-}=\mathrm{C}=\mathrm{N}^{+} \mathrm{R}_{2}$ with double bond $\mathrm{C}(1)=\mathrm{N}(2)$ [20]. This data is in agreement with slightly nonlinear structure of the fragment $\mathrm{Pt}(1)-\mathrm{N}(1)-\mathrm{C}(1)$ and it is also supported by the previous investigations of complexes of similar structures $[4,16]$.

The angles around the $\mathrm{N}(2)$ atom are close to $120^{\circ}$ varying from $116.18(13)^{\circ}$ to $119.89(15)^{\circ}$ thus pointing out the $\mathrm{sp}^{2}$ hybridization of the $\mathrm{N}(2)$ atom and the amide character of the $\mathrm{NR}_{2}$ group. The piperidine ring has a typical chair conformation and all bond lengths are usual for single $\mathrm{C}-\mathrm{C}$ bonds

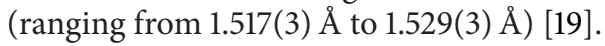

\section{Conclusion}

The novel complex trans- $\left[\mathrm{PtI}_{2}\left(\mathrm{NCNC}_{5} \mathrm{H}_{10}\right)_{2}\right]$ bearing the push-pull nitrile ligands was prepared in high yield and characterized by IR, ${ }^{1} \mathrm{H}$ and ${ }^{13} \mathrm{C}$ NMR spectroscopy, and high resolution ESI-MS. Proposed structure was confirmed by single crystal X-ray diffraction. The trans-effect of $\mathrm{I}^{-}$ligands determines the selective generation of trans-isomer.

Platinum has square planar environment with almost linear fragment $\mathrm{Pt}(1)-\mathrm{N}(1)-\mathrm{C}(1)-(\mathrm{N} 2)$. The bond length 
TABLE 2: Selected bond lengths and angles $\left(\AA,^{\circ}\right)$.

\begin{tabular}{lccc}
\hline $\mathrm{Pt}(1)-\mathrm{N}(1)$ & $1.9537(15)$ & $\mathrm{N}(1)-\mathrm{Pt}(1)-\mathrm{I}(1) \# 1$ & $90.69(5)$ \\
$\mathrm{Pt}(1)-\mathrm{I}(1)$ & $2.6117(2)$ & $\mathrm{N}(1)-\mathrm{Pt}(1)-\mathrm{I}(1)$ & $89.31(5)$ \\
$\mathrm{N}(1)-\mathrm{C}(1)$ & $1.153(2)$ & $\mathrm{N}(1)-\mathrm{C}(1)-\mathrm{N}(2)$ & $178.1(2)$ \\
$\mathrm{N}(2)-\mathrm{C}(1)$ & $1.314(2)$ & $\mathrm{C}(1)-\mathrm{N}(1)-\mathrm{Pt}(1)$ & $178.37(15)$ \\
$\mathrm{N}(2)-\mathrm{C}(6)$ & $1.477(2)$ & $\mathrm{C}(1)-\mathrm{N}(2)-\mathrm{C}(6)$ & $119.89(15)$ \\
$\mathrm{N}(2)-\mathrm{C}(2)$ & $1.478(2)$ & $\mathrm{C}(1)-\mathrm{N}(2)-\mathrm{C}(2)$ & $117.16(15)$ \\
& & $\mathrm{C}(6)-\mathrm{N}(2)-\mathrm{C}(2)$ & $116.18(13)$ \\
\hline
\end{tabular}

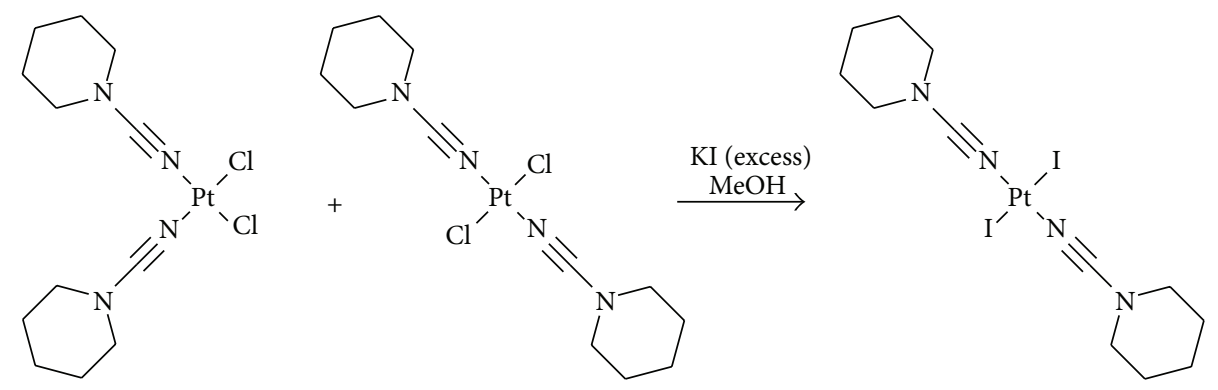

Scheme 1: Preparation of trans- $\left[\mathrm{PtI}_{2}\left(\mathrm{NCNC}_{5} \mathrm{H}_{10}\right)_{2}\right]$.

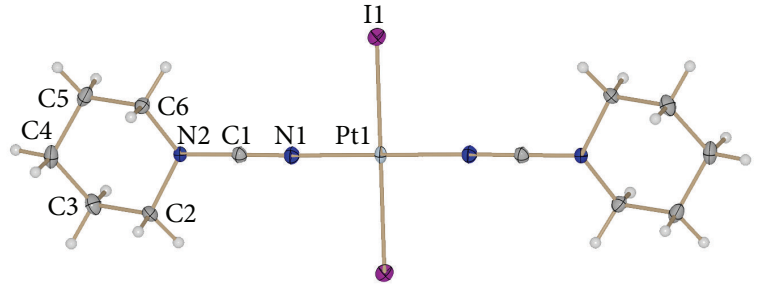

Figure 1: The molecular structure of trans- $\left[\mathrm{PtI}_{2}\left(\mathrm{NCNC}_{5} \mathrm{H}_{10}\right)_{2}\right]$, showing the atom-labeling scheme and displacement ellipsoids drawn at the $50 \%$ probability level.

$\mathrm{C}(1)-\mathrm{N}(1)$ is close to double $\mathrm{C}=\mathrm{N}$ bond that is caused by significant contribution of $\mathrm{N}^{-}=\mathrm{C}=\mathrm{N}^{+} \mathrm{R}_{2}$ structure stabilized by the platinum(II) center.

\section{Acknowledgments}

The authors would like to thank the Russian Fund for Basic Research (Grants 12-03-00076 and 12-03-33071) and Saint Petersburg State University for the research Grant 2013-2015 (12.38.781.2013). The authors also acknowledge the Centre for Magnetic Resonance of Saint Petersburg State University for performing of NMR studies. L. D. Funt is thanked for experimental assistance at an early stage of the project.

\section{References}

[1] V. Y. Kukushkin and A. J. L. Pombeiro, "Additions to metalactivated organonitriles," Chemical Reviews, vol. 102, no. 5, pp. 1771-1802, 2002.

[2] N. A. Bokach, M. L. Kuznetsov, and V. Y. Kukushkin, "1,3Dipolar cycloaddition of nitrone-type dipoles to uncomplexed and metal-bound substrates bearing the Ctriple bond, longN triple bond," Coordination Chemistry Reviews, vol. 255, no. 2324, pp. 2946-2967, 2011.

[3] D. S. Bolotin, N. A. Bokach, M. Haukka, and V. Y. Kukushkin, "Amidoximes provide facile platinum(II)-mediated oximenitrile coupling," Inorganic Chemistry, vol. 51, pp. 5950-5964, 2012.

[4] P. V. Gushchin, N. A. Bokach, M. Haukka, E. S. Dmitrieva, and V. Y. Kukushkin, "Trans-dichlorobis(piperidine-1-carbonitrile)platinum(II)," Acta Crystallographica E, vol. 62, no. 2, pp. m244$\mathrm{m} 246,2006$

[5] Bruker AXS, SAINT, Bruker AXS, Madison, Wis, USA, 2009.

[6] G. M. Sheldrick, "A short history of SHELX," Acta Crystallographica A, vol. 64, part 1, pp. 112-122, 2008.

[7] L. J. Farrugia, "WinGX suite for small-molecule single-crystal crystallography," Journal of Applied Crystallography, vol. 32, no. 4, pp. 837-838, 1999.

[8] G. M. Sheldrick, SADABS-Bruker Nonius Scaling and Absorption Correction, Bruker AXS, Madison, Wis, USA, 2008.

[9] T. T. B. Ha, F. L. Wimmer, J.-P. Souchard, N. P. Johnson, and J. Jaud, "Substitution of pyridine ligands from platinum(II) iodo complexes by dimethyl sulphoxide: crystal structure of trans-(3,5-dimethylpyridine)(dimethyl sulphoxide-S)diiodoplatinum," Journal of the Chemical Society, Dalton Transactions, pp. 1251-1255, 1990.

[10] L. S. Hollis, E. W. Stern, A. R. Amundsen, A. V. Miller, and S. L. Doran, "Platinum complexes of vitamin C. NMR studies on the solution chemistry of cis-Pt(diamine)(ascorbate) complexes," Journal of the American Chemical Society, vol. 109, no. 12, pp. 3596-3602, 1987.

[11] L. Rigamonti, A. Forni, M. Manassero, C. Manassero, and A. Pasini, "Cooperation between cis and trans influences in cis$\mathrm{Pt}^{I I}\left(\mathrm{PPh}_{3}\right)_{2}$ complexes: structural, spectroscopic, and computational studies," Inorganic Chemistry, vol. 49, no. 1, pp. 123-135, 2010.

[12] N. Margiotta, C. Marzano, V. Gandin et al., "Revisiting $\left[\mathrm{PtCl}_{2}(\mathrm{cis}-1,4-\mathrm{DACH})\right]$ : an underestimated antitumor drug 
with potential application to the treatment of oxaliplatinrefractory colorectal cancer," Journal of Medicinal Chemistry, vol. 55, no. 16, pp. 7182-7192, 2012.

[13] K. H. Chaudhari, U. S. Mahajan, D. S. Bhalerao, and K. G. Akamanchi, "Novel and facile transformation of N,N-disubstituted glycylamides into corresponding cyanamides by using pentavalent iodine reagents in combination with tetraethylammonium bromide," Synlett, no. 18, pp. 2815-2818, 2007.

[14] W. P. Fehlhammer, R. Metzner, and W. Sperber, "Metallkomplexe funktioneller isocyanide, XXIV. Reaktionen von N-isocyandialkylamin-metallkomplexen mit sekundären aminen," Chemische Berichte, vol. 127, no. 5, pp. 829-833, 1994.

[15] Y. Y. Scaffidi-Domianello, K. Meelich, M. A. Jakupec et al., "Novel cis- and trans-configured bis(oxime)platinum(II) complexes: synthesis, characterization, and cytotoxic activity," Inorganic Chemistry, vol. 49, no. 12, pp. 5669-5678, 2010.

[16] N. A. Bokach, T. B. Pakhomova, V. Y. Kukushkin, M. Haukka, and A. J. L. Pombeiro, "Hydrolytic metal-mediated coupling of dialkylcyanamides at a $\mathrm{Pt}(\mathrm{IV})$ center giving a new family of diimino ligands," Inorganic Chemistry, vol. 42, no. 23, pp. 75607568, 2003.

[17] H. H. Eysel, E. Guggolz, M. Kopp, and M. L. Ziegler, "Darstellung und Charakterisierung von cis- und trans-Bis(benzonitril)dichloroplatin(II) Rntgenstrukturanalysen der cis- und trans-Spezies," Zeitschrift für anorganische und allgemeine Chemie, vol. 499, pp. 31-43, 1983.

[18] P. Svensson, K. Lovqvist, V. Y. Kukushkin, and A. Oskarsson, "Thermal Cis to trans isomerization of $\left[\mathrm{PtCl}_{2}\left(\mathrm{C}_{2} \mathrm{H}_{5} \mathrm{CN}\right)_{2}\right]$ and crystal structures of the cis- and trans-isomers," Acta Chemica Scandinavica, vol. 49, pp. 72-75, 1995.

[19] F. H. Allen, O. Kennard, D. G. Watson, L. Brammer, A. G. Orpen, and R. Taylor, "Tables of bond lengths determined by $\mathrm{x}$-ray and neutron diffraction. Part 1 . Bond lengths in organic compounds," Journal of the Chemical Society, no. 12, pp. S1-S19, 1987.

[20] T. B. Anisimova, N. A. Bokach, I. O. Fritsky, and M. Haukka, "Trans-ligand-dependent arrangement (bent or linear) of $\mathrm{Pt}^{\mathrm{II}}$-bound dialkylcyanamide ligands: molecular structure of trans-dichloro(dimethylcyanamide)(dimethyl sulfoxide)platinum(II)," Journal of Molecular Structure, vol. 1005, no. 1-3, pp. 141-143, 2011. 

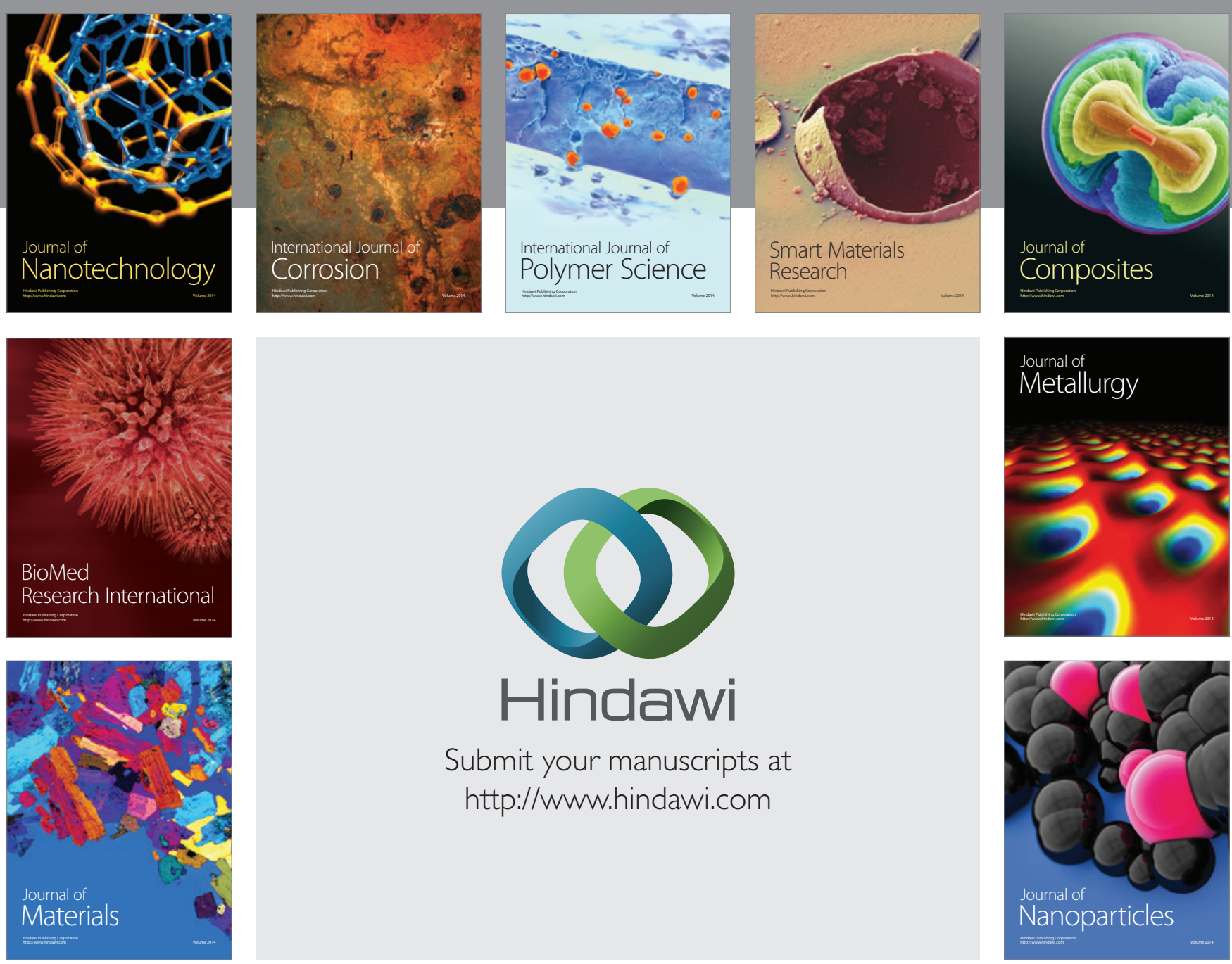

Submit your manuscripts at http://www.hindawi.com
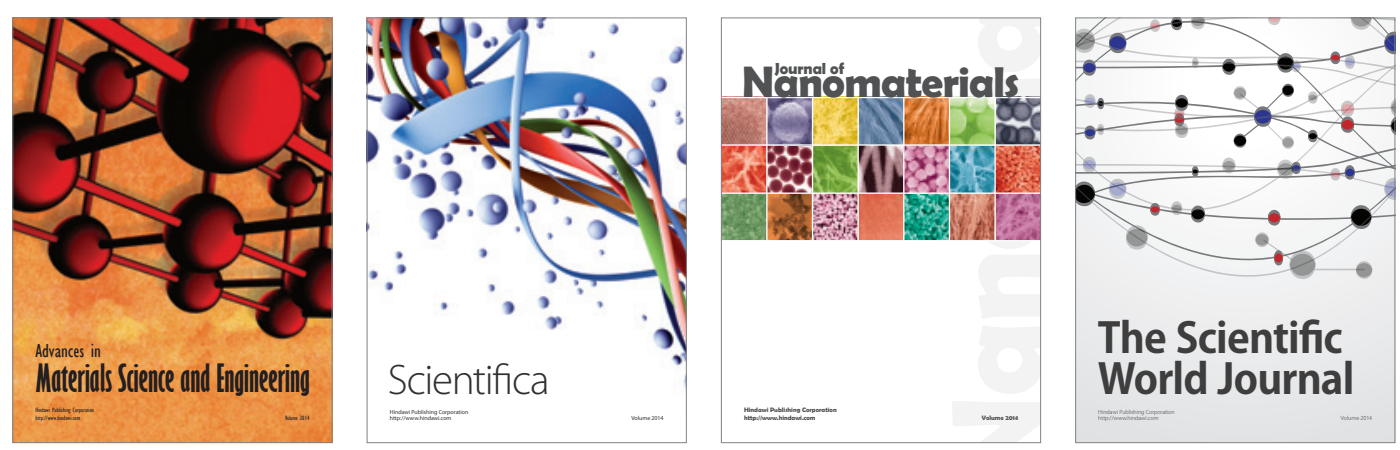

\section{The Scientific World Journal}
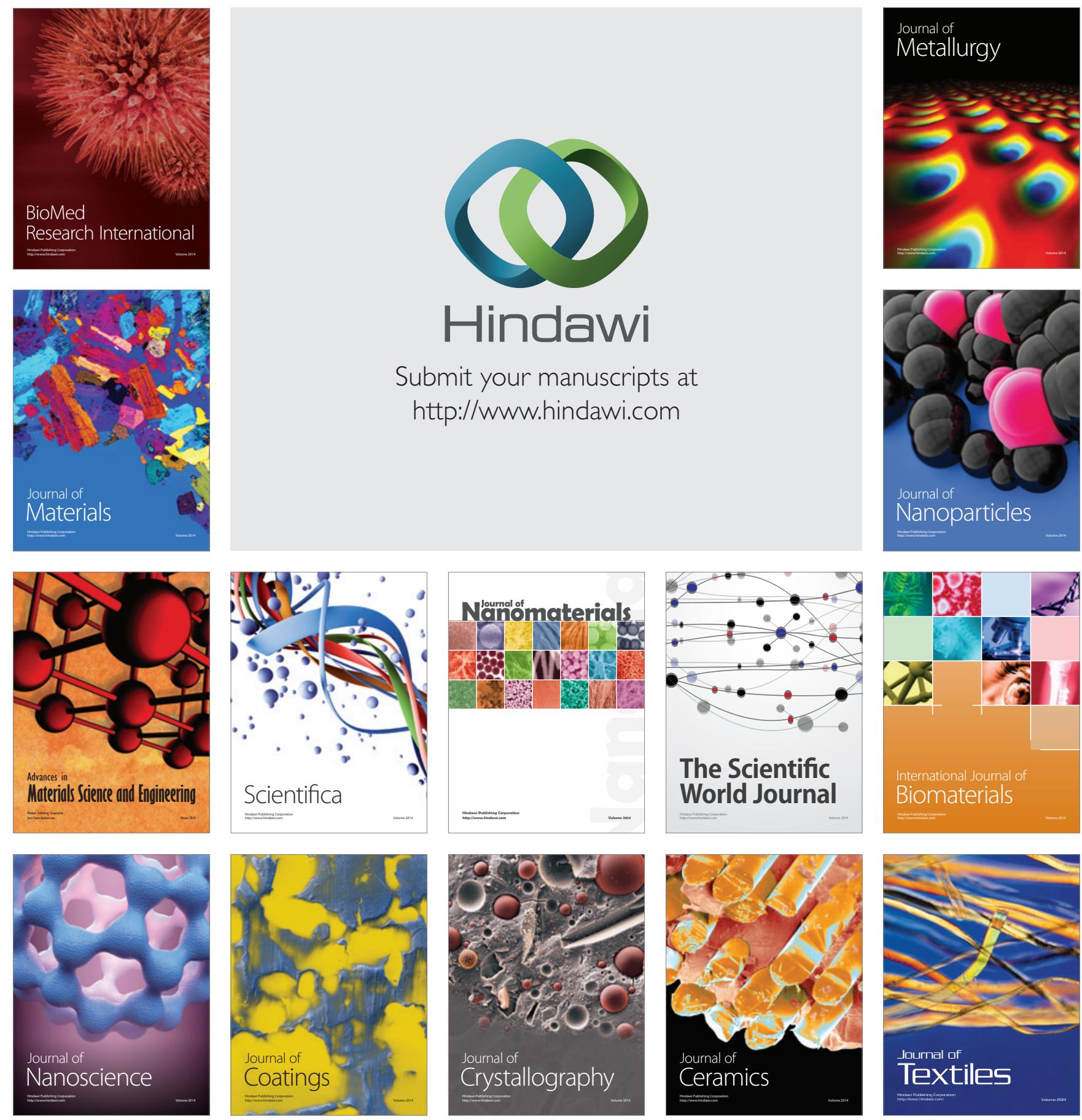